\title{
Pengaruh Pelayanan dan Kepuasan Terhadap Loyalitas Anggota Pembiayaan di BMT Al-Falah Sumber Cirebon.
}

\author{
Nur Haida, Kurnia \\ Prodi Ekonomi Syariah Institut Agama Islam Bunga Bangsa Cirebon \\ E-mail : nurhaida26684@gmail.com, kurnianada13@gmail.com
}

\begin{abstract}
Abstrak
Kualitas produk, pelayanan, dan profitabilitas perusahaan adalah tiga hal yang terkait erat. Semakin tinggi kualitas, semakin tinggi kepuasan pelanggan yang dihasilkan, yang mendukung harga yang lebih tinggi dan sering kali biaya yang lebih rendah. Studi telah memperlihatkan korelasi yang tinggi antara kualitas produk atau jasa dengan profitabilitas perusahaan. Kondisi persaingan bisnis, kemajuan teknologi, perkembangan ekonomi, dan sejarah masyarakat mendorong terjadinya pengembangan kualitas pelayanan (service quality) yang menekankan pada pentingnya pemenuhan harapan dan kebutuhan nasabah. Terus maningkatnya jumlah anggota BMT Al-Falah Sumber Cirebon, terdapat juga anggota yang tidak loyal walaupun pelayanan yang diberikan BMT Al-Falah Sumber Cirebon itu cukup bagus dan mereka para anggota merasa puas dengan pelayanan yang diberikan. Penelitian ini bertujuan untuk mengetahui seberapa besar sistem pelayanan dan kepuasan nasabah terhadap loyalitas anggota pembiayaan di BMT Alfalah Sumber Cirebon. Penelitian ini merupakan penelitian kuantitatif, dengan menggunakan metode pengumpulan data kuisioner, dengan analisis regresi berganda yang menguji hipotesis penelitian. Berdasarkan hasil analisis data dalam penelitian ini menunnjukkan bahwa variabel sistem pelayanan berpengaruh positif sebesar 0,081 tetapi dari hasil uji $t$ nilai probabilitas (sig) tidak mempunyai pengaruh secara signifikan terhadap loyalitas anggota sebesar 0,021. Probabilitas (sig) sistem pelayanan sebesar 0,021 >0,05 dengan demikian Ho ditolak. Hal ini diinterpretasikan bahwa sistem pelayanan tidak mempunyai pengaruh yang signifikan terhadap loyalitas anggota pembiayaan di BMT Al-falah Sumber Cirebon. Sedangkan variabel kepuasan berpengaruh positif sebesar 0,240 tetapi dari hasil uji $t$ nilai probabilitas (sig) tidak mempunyai pengaruh secara signifikan terhadap loyalitas anggota sebesar 0,010 > 0,05 dengan demikian Ho ditolak. Hal ini diinterpretasikan bahwa kepuasan tidak mempunyai pengaruh yang signifikan terhadap loyalitas anggota pembiayaan di BMT Al-falah Sumber Cirebon. Dan hasil uji Pengaruh sistem pelayanan dan kepuasan terhadap loyalitas anggota pembiayaan di BMT Al-falah

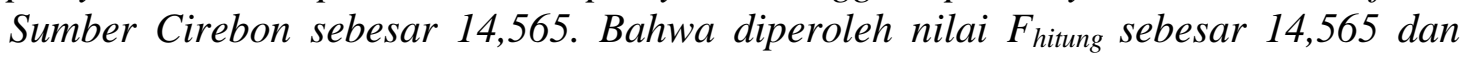
nilai sig. 0,000. Kemudian perbandingan antara $F_{\text {tabel }}$ dengan $F_{\text {hitung }}$ dengan menggunakan batas signifikan 0,05 dan $F_{\text {tabel }} 2,32$. Dapat dilihat bahwa $F_{\text {hitung }}>F_{\text {tabel }}$ yaitu 14,565 > 2,32 dengan demikian Ha diterima dan HO ditolak.
\end{abstract}

Kata Kunci, Kepuasan Nasabah, Kualitas Pelayanan, Loyalitas Anggota 


\begin{abstract}
The quality of the product, service, and profitability of the company are three things that are closely related. The higher the quality, the higher the resulting customer satisfaction, which supports higher prices and often lower costs. Studies have shown a high correlation between product or service quality with firm profitability. The condition of business competition, technological progress, economic development, and community history encourage the development of service quality which emphasizes the importance of fulfilling the expectations and needs of the customers. The increasing number of members of BMT Al-Falah Sumber Cirebon, there are also members who are not loyal although the services provided by BMT Al-Falah Source Cirebon is pretty good and they are satisfied with the service provided. This study aims to find out how big the service system and customer satisfaction of loyalty of financing members in BMT Alfalah Sumber Cirebon. This research is a quantitative research, using questionnaire data collection method, with multiple regression analysis that tested the research hypothesis. Based on the results of data analysis in this study menunnjukkan that service system variables have a positive effect of 0.081 but from the test results $t$ probability (sig) does not have a significant effect on loyalty of members of 0.021 . The probability (sig) of service system is 0.021>0.05 thus Ho is rejected. It is interpreted that the service system has no significant effect on loyalty of finance member in BMT Al-falah Sumber Cirebon. While the satisfaction variable has a positive effect of 0.240 but from the test result t the probability (sig) does not have a significant effect on the loyalty of members of $0.010>0.05$ thus Ho is rejected. It is interpreted that satisfaction has no significant effect on loyalty of finance member in BMT Al-falah Sumber Cirebon. And test result Influence of service system and satisfaction to loyalty member of financing in BMT Al-falah Source Cirebon equal to 14,565. That obtained Fcount value of 14,565 and sig value. 0,000. Then the comparison between Ftable with Fhitung by using the significant limit of 0.05 and Ftabel 2.32. It can be seen that Fcount> Ftable is 14,565> 2,32 thus Ha is received and $\mathrm{HO}$ is rejected.
\end{abstract}

Keywords: Customer Satisfaction, Service Quality, Member Loyalty

\section{PENDAHULUAN}

Pelayanan merupakan sebuah keniscayaan upaya yang harus dilakukan oleh setiap perusahan untuk memenuhi kepuasan nasabah. Dalam pelayanan yang diberikan kepada para nasabah akan menjadi tolak ukur sejauhmana pihak lembaga bank atau non bank mampu memberikan yang terbaik kepada setiap para nasabahnya. Pelayanan yang mampu dilakukan secara langsung maupun tidak langsung dalam menganalisa yang bersifat menyeluruh. Setiap pelayanan yang berlaku terhadap kegiatan keuangan analisanya dapat meliputi aspek sebagai penentu kegiatan perbankan dan faktor- faktor yang mempengaruhinya, masalah transaksi dan pengawasan operasional lembaga keuangan dari sudut syariahnya, bentuk-bentuk kebijakan yang telah dibuat untuk menghadapi masalah yang muncul.

Pelayanan merupakan cara langsung atau tidak langsung yang menuntut untuk menganalisa kegiatan yang berlaku dengan cara mengetahui aspek-aspek kecil dari keseluruhan kegiatan dalam pembiayaan dan simpanan pada lembaga keuangan.

Perkembangan didunia lembaga keuangan bank atau non bank khususnya lembaga keuangan keuangang non bank yang tidak lepas dari persaingan pasar 
ini menentut para lembaga keuangan non bank untuk kreatif dan berinovasi dalam menjalankan visi dan misinya agar dapat bertahan. Salah satu lembaga keuangan non bank yang memiliki persaingan yang tinggi adalah di BMT Alfalah Sumber Cirebon.

Kepuasan pelanggan merupakan faktor yang sangat menentukan dalam pemasaran, sebaliknya kekecewaan pelanggan dalam memberi layanan bisa menjadikan kehancuran perusahaan di masa mendatang. Agar pelanggan dapat dipertahankan, tentu harus dilakukan dengan langkah-langkah pelayanan optimal bagi pelanggan. Menurut Francis Buttle "Naiknya tingkat kepuasan akan meningkat pula kecenderungan konsumen untuk kembali membeli produk yang ditawarkan perusahaan". Hal ini kuat hubunganya dengan kualitas yang terdapat pada produk yang ditawarkan oleh perusahaan. Menurut Kotler dan Keller (2009 : 143-144) bahwa kualitas adalah jaminan terbaik perusahaan, pertahanan terkuat dari perusahaan dalam menghadapi persaingan dan satu-satunya jalan untuk mempertahankan pertumbuhan dan penghasilan. ${ }^{1}$

Kualitas produk, pelayanan, dan profitabilitas perusahaan adalah tiga hal yang terkait erat. Semakin tinggi kualitas, semakin tinggi kepuasan pelanggan yang dihasilkan, yang mendukung harga yang lebih tinggi dan sering kali biaya yang lebih rendah. Studi telah memperlihatkan korelasi yang tinggi antara kualitas produk atau jasa dengan profitabilitas perusahaan. Kondisi persaingan bisnis, kemajuan teknologi, perkembangan ekonomi, dan sejarah masyarakat mendorong terjadinya pengembangan kualitas pelayanan (service quality) yang menekankan pada pentingnya pemenuhan harapan dan kebutuhan nasabah. Adanya pelayanan

\footnotetext{
${ }^{1}$ Kotler dan Keller . Manajemen

Pemasaran.(Jakarta:Rajawali Press Grasindo 2009) h $143-144$
}

yang baik akan memberikan kontribusi pada pencapaian kepuasan nasabah yang memegang peranan sangat penting bagi kelangsungan hidup perusahaan atau lembaga. Seperti yang dijelaskan dalam Qs al-baqarah ayat $267^{2}$ :

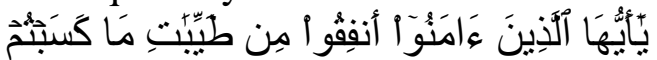

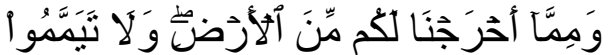

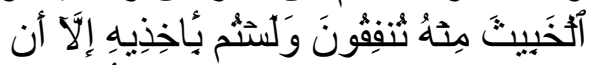

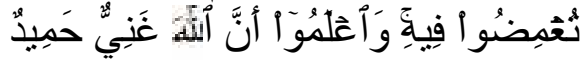

Artinya : "Hai orang-orang yang beriman, nafkahkanlah (di jalan Allah) sebagian dari hasil usahamu yang baikbaik dan sebagian dari apa yang kami keluarkan dari bumi untuk kamu. dan janganlah kamu memilih yang burukburuk lalu kamu menafkahkan daripadanya, padahal kamu sendiri tidak mau mengambilnya melainkan dengan memincingkan mata terhadapnya. dan Ketahuilah, bahwa Allah Maha Kaya lagi Maha Terpuji."

Sejak didirikannya BMT Al-Falah Sumber Cirebon jumlah anggotanya terus meningkat. Hal tersebut menunjukan bahwa masyarakat telah mengenal nama dan citra dari BMT AlFalah Sumber Cirebon baik melalui informasi mulut ke mulut maupun pengalaman dari seseorang yang terdekat yang telah menjadi anggota. Selain itu juga letak BMT Al-Falah Sumber tidak jauh dari pasar Sumber sehingga banyak pedagang ataupun masyarakat sekitarnya yang menggunakan jasa BMT Al-Falah Sumber tersebut.

Faktor lain dalam sistem pelayanan yang dapat mempengaruhi anggota terhadap loyalitas adalah fasilitas. Faktor ini sangat mendukung terhadap kualitas pelayanan yang diberikan, factor sarana dan prasarana seperti tata ruang yang nyaman, peralatan yang memadai untuk para anggotanya. Dengan fasilitas yang memadai maka anggota akan merasa

\footnotetext{
${ }^{2}$ Departemen Agama RI, Al-Qur'an dan Terjemah juz 1-juz 30, (Jakarta: Dana Karya, 2002), h. 56.
} 
puas untuk melakukan transaksi di bank BMT tersebut.

Terus maningkatnya jumlah anggota BMT Al-Falah Sumber Cirebon, terdapat juga anggota yang tidak loyal walaupun pelayanan yang diberikan BMT Al-Falah Sumber Cirebon itu cukup bagus dan mereka para anggota merasa puas dengan pelayanan yang diberikan. Ada beberapa faktor mengharuskan untuk mengundurkan diri dari daftar nama anggota di BMT AlFalah Sumber Cirebon walaupun tidak menutupi kemungkinan para anggota merasa puas terhadap pelayanan yang diberikan. Beberapa faktornya anatara lain karena pindah kerja atau pindah tempat tinggal sehingga mereka terpaksa menutup rekeningnya. Penelitian ini bertujuan untuk mengetahui seberapa besar sistem pelayanan dan kepuasan nasabah terhadap loyalitas anggota pembiayaan di BMT Alfalah Sumber Cirebon.

\section{Penelitian yang Relevan}

Penelitian terdahulu sangatlah dibutuhkan untuk mendukung, menambah, memperkuat, atau bahkan menolak penelitian sebelumnya. Sebelumnya telah ada peneliti yang menggunakan teori pelayanan yang dikaitkan dengan loyalitas nasabah.

Berikut ini peneliti yang melakukan penelitian yang dikaitkan dengan pelayanan terhadap loyalitas anggota yang telah dilakukan diantaranya yaitu: Penelitian dengan judul Pengaruh Kualitas Pelayanan Terhadap Loyalitas Nasabah studi di Bank Pembiayaan Rakyat Syariah (BPRS) Bangun Drajat Warga (BDW) Yogayakarta oleh Mukaddam (2014). Dari penelitian tersebut berdasarkan perhitungan determinasi diketahui adjusted $R$ Square antara variabel kualitas pelayanan dengan loyalitas nasabah BPRS BDW Yogyakarta sebesar $24,8 \%$ menjelaskan bahwa ada pengaruh kedua variabel positif. Artinya semakin baik kualitas pelayanan yang diberikan BPS BDW Yogyakarta terhadap nasabahnya maka akan semakin tinggi loyalitas nasabah BPRS BDW Yogayakarta.

Berdasarkan pedoman Guilford, pengaruh antara variabel kualitas pelayanan dengan loyalitas nasabah BPRS BDW Yogaykarta sebesar 24,8\% dikategorikan cukup berarti, artinya loyalitas pada nasabah tidak hanya dipengaruhi oleh kualitas pelayanan semata. Melainkan ada 75,2\% faktor lain yang mempengaruhi loyalitas nasabah BPRS BDW Yogyakarta.

Dapat disimpulkan bahwa ada pengaruh yang cukup signifikan antara kualitas pelayanan terhadap loyalitas nasabah BPRS BDW Yogayakarta. Sehingga hipotesis Ho ditolak dan hipotesis Ha diterima yang berarti ada pengaruh yang positif antara kedua variabel tersebut.

\section{Hipotesis Penelitian}

1. Hipotesis (Ho) tidak terdapat pengaruh sistem pelayanan terhadap loyalitas anggota pembiayaan BMT Al-Falah Sumber Cirebon dan hipotesis (Ha) terdapat pengaruh sistem pelayanan terhadap loyalitas anggota pembiayaan BMT AlFalah Sumber Cirebon.

2. Hipotesis (Ho) tidak terdapat pengaruh kepuasan terhadapat loyalitas anggota pembiayaan BMT Al-Falah Sumber Cirebon dan hipotesis (Ha) terdapat pengaruh kepuasan terhadapat loyalitas anggota pembiayaan BMT Al-Falah Sumber Cirebon

3. Hipotesis (Ho) tidak terdapat pengaruh sistem pelayanan dan kepuasan terhadapat loyalitas anggota pembiayaan BMT Al- 
Falah Sumber Cirebon dan hipotesis (Ha) terdapat pengaruh sistem pelayanan dan kepuasan terhadapat loyalitas anggota pembiayaan BMT Al-Falah Sumber Cirebon.

\section{Metode Penelitian}

Penelitian ini merupakan penelitian kuantitatif, dengan menggunakan metode pengumpulan data kuisioner, kuisioner merupakan metode pengumpulan data primer yang menggunakan pertanyaan lisan dan tertulis. Berdasarkan metode ini memerlukan kontak hubungan antara peneliti dengan subjek (responden) agar diperoleh data yang diperlukan. ${ }^{3}$

Metode ini digunakan untuk memperoleh pembuktian, yang pertama: tentang bagaimana sistem pelayanan terhadap loyalitas anggota pembiayaan. Yang kedua: bagaimana pengaruh kepuasaan terhadap loyalitas anggota pembiayaan. Dan yang terakhir untuk mengaetahui penagruh sistem pelayanan dan kepuasan terhadap loyalitas anggota pembiayaan. Yakni di Koperasi Simpan Pinjam dan Pembiayaan Syari'ah (KSPPS) BMT Al-Falah Berkah Sejahtera Sumber.

\section{Populsi dan Sampel}

Populsi adalah kelompok elemen yang lengkap, yang biasanya berupa orang atau objek, transaksi, atau kejadian dimana kita tertarik untuk mempelajarinya atau menjadi objek penelitian. ${ }^{4}$ Populasi dalam penelitian ini adalah angggota Pembiayaan di BMT Alfalah Sumber Cirebon.

Sampel adalah bagian dari jumlah dan karakteristik yang dimiliki

3 Etta Mamang Sangadji dan sopiah, 2012, Metodologi Penelitian Pendekatan Praktis dalam Penelitian, Yogyakarta: And, h. 302.

${ }^{4}$ Mudrajat Kuncoro, Metode riset untuk bisnis dan ekonom, Jogjakarta, Erlangga, 2013, h. 118. oleh populasi. ${ }^{5}$ Dalam pengambilan sampel teknik yang digunakan dalam penelitian ini adalah non probability sampling, yaitu semua elemen dalam populasi tidak memiliki kesempatan yang sama untuk dipilih menjadi sampel. Hal ini dilakukan karena mengingat keterbatasan waktu yang ada, maka metode pengambilan sampel mengunakan convenience sampling, yaitu pengambilan sampel berdasarkan kebetulan, siapa aja yang kebetulan bertemu dengan penelitian, dapat digunkan sebagai sampel jika responden dipandang cocok sebagai sumber data.

Sampel dalam penelitian ini adalah sebagian dari anggota pembiayaan BMT Al-Falah Sumber Cirebon karena jumlahnya yang terlalu banyak dan keterbatasan waktu maka yang ada, ada sebuah rumus yang digunakan untuk menentukan besaran sampel, dengan menggunakan rumus slovin yang hasilnya adalah diambil 90 sampel penelitian. ${ }^{6}$

\section{PEMBAHASAN \\ Baitul Maal Wa Tamwil (BMT)}

Bait al-Mal wa Tamwil berasal dari tiga kata, yaitu bait, al-mal dan tamwil. Kata bait berarti "rumah", almal berarti "harta" yang asal katanya adalah Maal atau harta dan Tamwil berarti "pengembangan harta kekayaan". Pengertian suku kata itulah yang kemudian digunakan sebagai rumah tempat mengumpulkan atau menyimpan harta dan tempat penanaman modal untuk lembaga keuangan mikro, yaitu berfungsi sebagai lembaga pengembangan usaha.. Adapun secara terminologi, Bait al-Mal adalah suatu

\footnotetext{
${ }^{5}$ Sugiyono, Managemen Bank Syariah,

(Yogyakarta: Unit Penerbit Dan Percetak: 2013), h. 118 .

${ }^{6}$ Bambang Prasetyo dan Lina Miftahul Jannah, Metode Penelitian Kuantitatif, (Jakarta: PT Raja Grafindo Persada, 2013) h. 137-138.
} 
lembaga atau pihak yang mempunyai tugas khusus menangani segala harta umat, baik berupa pendapatan maupun pengeluaran negara. Di samping itu, Bait al-Mal juga dapat diartikan secara fisik, yaitu tempat menyimpan dan mengelola segala macam harta yang menjadi pendapatan negara.

Baitul Maal Wa Tamwil menurut Ahmad Hasan Ridwan (2013) Adalah "balai usaha mandiri terpadu yang isinya berintikan bayt al-mal wa at-tanwil dengan kegiatan mengembangkan usahausaha produktif dan investasi dalam meningkatkan kualitas kegiatan ekonomi pengusaha kecil bawah dan kecil dengan mendorong kegiatan menabung dan menunjang pembiayaan kegiatan ekonominya".

Selain itu, BMT juga dapat menerima titipan zakat, infak, dan sedekah, serta menyalurkannya sesuai dengan peraturan dan amanatnya. BMT merupakan lembaga ekonomi atau lembaga keuangan syariah nonperbankan yang bersifat informal karena lembaga ini didirikan oleh kelompok swadaya Masyarakat (KSM). ${ }^{7}$

\section{Sejarah Bait Al-Mal wa Tamwil}

Ketika umat Islam mendapatkan harta rampasan (ganimah) pada Perang Badar. Waktu itu, para sahabat berselisih paham tentang cara pembagian harta rampasan, sehingga turun firman Allah yang menerangkan tentang menetapkan hukum pembagian harta rampasan perang yang menjadi hak bagi seluruh umat Islam. Selain itu, Allah juga memberi kewenangan kepada Rasulullah untuk membagikannya, sesuai dengan pertimbangan beliau mengenai kemaslahatan umat Islam. Jadi, ganimah Perang Badar menjadi hak Bait al-Mal,

\footnotetext{
${ }^{7}$ Ahmad Ridwan Hasan, 2013, Manajemen Baitul Mal wa Tamwil, Bandung, CV Pustaka Setia. h. 22-23.
}

yang pengelolaannya dilakukan oleh kepala negara pada saat itu.

Pada masa itu, Bait al-Mal mempunyai pengertian sebagai pihak yang menangani setiap harta benda umat Islam, baik perolehan maupun pengeluarannya. Bait al-Mal waktu itu belum mempunyai tempat khusus untuk menyimpan harta, karena harta yang diperoleh belum begitu banyak. Kalaupun ada, harta yang diperoleh selalu habis dibagi-bagikan kepada masyarakat, atau dikeluarkan untuk kepentingan mereka. Maksudnya, Rasulullah senantiasa membagi harta rampasan kepada umat Islam seusai perang, setelah mengeluarkan seperlima (al-khumus) untuk dirinya.

Handhalah ibn Zaifiy, salah seorang sekretaris beliau mengatakan: "Rasulullah menugaskan dan mengingatkan aku untuk membagi harta rampasan perang yang diperoleh, setelah hari ketiga. Tidak ada harta atau makanan yang diberikan kepadaku selama tiga hari, kecuali Rasulullah mengingatkan untuk segera mendistribusikannya. Rasulullah tidak merasa nyaman tidurnya dalam satu malam, jika masih ada harta masyarakat berada di sisinya".

Dengan kata lain, jika harta itu datang pada pagi hari, akan segera dibagikan sebelum tengah hari tiba. Demikian pula, jika harta itu datang pada siang hari, maka segera dibagikan sebelum malam tiba. Karenanya, pada saat itu, belum banyak harta tersimpan yang mengharuskan adanya tempat dan arsip tertentu bagi pengelolaannya. ${ }^{8}$

\section{Ciri-ciri utama BMT \\ BMT merupakan lembaga milik masyarakat, sehingga keberadaannya

\footnotetext{
${ }^{8}$ https://zarchisme.wordpress.com/2009/11/21/bmtsejarah-masa-depannya/
} 
akan selalu dikontrol dan diawasi oleh masyarakat. Laba atau keuntungan yang diperoleh BMT juga akan didistributor kepada masyarakat, sehingga maju mundurnya BMT sangat dipengaruhi oleh masyarakat di sekitar BMT itu berada. Sebagai lembaga usaha yang mandiri, BMT memiliki ciri-ciri sebagai berikut:

1) Berorientasi beisnis, yaitu memiliki tujuan untuk mencari laba bersama dan meningkatkan pemanfaatan segala potensi ekonomi yang sebanyakbanyaknya bagi para anggota dan lingkungannya.

2) Bukan merupakan lembaga social, tetapi dapat dimanfaatkan untuk mengelola dana social umat, seperti zakat, infak, sedekah, hibah, dan wakaf.

3) Lembaga ekonomi umat yang dibangun dari bawah secara swadaya yang melibatkan peran serta masyarakat sekitarnya.

4) Lembaga ekonomi milk bersama antara kalangan masyarakat bawah dan kecil serta bukan milik perorangan atau kelompok tertentu di luar masyarakat sekitar BMT. ${ }^{9}$

\section{Tujuan BMT}

Terciptanya sistem, lembaga, dan kondisi kehidupan ekonomi rakyat banyak dilandasi oleh nilai-nilai dasar salam (keselamatan) berintikan keadilan, kedamaian, dan kesejahteraan, melandasi tumbuh dan berkembangnya tiga perempat usaha mikro dan kecil di seluruh Indonesia sebelum tahun 2014. ${ }^{10}$ Dalam dirkursus ekonomi Islam, BMT dapat pula dikategorikan dengan koperasi syariah, yaitu lembaga ekonomi yang berfungsi untuk menarik,

\footnotetext{
${ }^{9}$ Ahmad Ridwan Hasan. op. cit. h. 24.

${ }^{10}$ Ahmad Ridwan Hasan. op. cit. h. 26.
}

mengelola, dan menyalurkan dana diri, oleh, dan untuk masyarakat. Oleh sebab itu, BMT dapat disebut sebagai lembaga swadaya ekonomi umat yang dibentuk dari, oleh, dan untuk masyarakat.

BMT dapat didirikan dalam bentuk Kelompok Swadaya Masyarakat (KSM) atau koperasi.

a. KSM adalah Kelompok Swadaya Masyarakat dengan mendapatkan surat keterangan operasional dan PINBUK (Pusat Inkubasi Bisnis Usaha Kecil)

b. Koperasi serbausaha atau koperasi syariah

c. Koperasi simpan pinjam syariah (KSP-P)

Sebelum menjalankan usahanya, Kelompok Swadaya Masyarakat harus mendapatkan sertifikat operasi dari PINBUK, sedangkan PINBUK harus mendapat pengakuan dari Bank Indonesia (BI) sebagai Lembaga Pengembangan Swadaya Masyarkat (LPSM) yang mendukung program proyek Hubungan Bank dengan Kelompok Swadaya Masyarakat yang dikelola oleh bank Indonesia (PHBKBI). Selain dengan badan hukum Kelompok Swadaya Masyarakat, BMT juga dapat didirikan dengan menggunakan badan hukum koperasi

Penggunaan badan hukum KSM dan Koperasi untuk BMT disebabkan BMT tidak termasuk dalam lembaga keuangan formal yng dijelaskan UU Nomor 1992 dan UU Nomor 10 Tahun 1998 tentang perbankan. ${ }^{11}$

Jadi BMT merupakan Lembaga Keuangan Mikro Syariah yang kegiatannya mencakup bidang baitul mal yaitu mengelola dana zakat, infak, sedekah (ZIS) dan bidang baitut tamwil, yaitu menerima simpanan tabungan anggota atau masyarakat calon anggota serta menyediakan pembiayaan usaha

\footnotetext{
${ }^{11}$ Ahmad Ridwan Hasan. op. cit. h. 27
} 
kecil (mikro) yang dilandasi dengan prinsip-prinsip syariah.

\section{Pelayanan}

Menurut kasmir (2005) pelayanan dapat didefinisikan sebagai tindakan atau perbuatan seseorang atau organisasi (kumpulan orang) untuk memberikan kepuasan kepada pelanggan atau nasabah, tindakan tersebut dapat dilakukan melalui cara langsung berhadapan dengan pelanggan dan melayani mereka berupa tindakan yang dilakukan guna memenuhi keinganan akan pelanggan akan suatu produk atau jasa yang mereka butuhkan. ${ }^{12}$

Jadi pelayanan merupakan serangkaian aktivitas yang bersifat langsung yang terjadi akibat adanya suatu interaksi antara konsumen dengan karyawan atau hal lain yang disediakan oleh perusahaan pemberi pelayanan yang dimaksud untuk memecahkan permasalahan-permasalahan konsumen / pelanggan."

Pelayanan dapat menciptakan kepuasan nasabah, apabila $\mathrm{CEO}$ /marketer memusatkan perhatian pada upaya pemuasan keinginan nasabah dengan menentukan nasabah sasaran yang sebenarnya (target market) yang akan dilayani, mengidentifikasikan keinginan nasabah, mengembangkan produk yang mampu memuaskan keinginan nasabah, rancang proses produk yang menghasilkan kesesuain dengan keinginan nasabah dan wujudkan rancangan proses produk tersebut kedalam kegiatan layanan dan promosi sehari-hari.

Industri pelayanan jasa bank yang mengandalkan upaya terbentuknya kepuasan nasabah adalah sebagai berikut

a. Service profi cycle, pelayanan yang baik diberikan oleh karyawan

\footnotetext{
${ }^{12}$ Kasmir, Etika Customer Service, Jakarta, Rajawali Press, 2005, h. 15.
}

yang akan menghasilkan kepuasan nasabah yang pada gilirannya akan membuahkan loyalitas dan darinya dapat diperoleh keuntungan bagi nasabah.

b. Service leverage, pemberian pelayanan yang bernilai lebih besar dibandingkan dengan nilai biaya yang digunakan nasabah untuk memperolehnya, oleh karena itu nasabah mempunyai kesan memperoleh pelayanan ekstra dan perhatian khusus akan mendorong tumbuhnya loyalitas pada nasabah.

c. Service ability, yaitu tingkat kemampuan pelayanan, kecepatan, dan kemudahan dalam mendapatkan pelayanan. ${ }^{13}$

Terdapat lima dimensi pelayanan menurut Parasuraman dalam Lupiyoadi (2006:182) ${ }^{14}$, yaitu:

a. Tangibles (bukti langsung), yaitu kemampuan perusahaan dalam menunjukkan eksistensinya kepada pihak eksternal. Yang dimaksud bahwa penampilan dan kemampuan sarana dan prasarana fisik perusahaan dan keadaan lingkungan sekitarnya adalah bukti nyata dan pelayanan yang diberikan.

b. Reliability (keandalan), yaitu kemampuan perusahaan untuk memberikan pelayanan sesuai yang dijanjikan secara akurat dan terpercaya.

c. Responsiveness (daya tangkap), yaitu suatu kemauan untuk membantu dan memberikan pelayanan yang cepat dan tepat kepada pelanggan, dengan penyampaian informasi yang jelas.

\footnotetext{
${ }^{13}$ Ali Hasan, Marketing Bank Syariah, Bogor, Ghalia Indonesia, 2010, h. 94.

${ }^{14}$ Rambat Lupiyoadi, 2006, Manajemen Pemasaran Jasa : Teori dan Pratek, Jakarta: PT salemba Empat, h.182.
} 
d. Assurance (jaminan dan kepastian), yaitu pengetahuan, kesopansantunan, dan kemampuan para pegawai perusahaan untuk menumbuhkan rasa percaya para pelanggan kepada perusahaan. Terdiri dari beberapa komponen antara lain komunikasi, kredibilitas, keamanan, kompetensi dan sopan santun.

e. Empathy (empati), yaitu memberikan perhatian yang tulus dan bersifat individual atau pribadi yang diberikan kepada para pelanggan dengan berupaya memahami keinginan pelanggan. Sebagai contoh perusahaan harus mengetahui keinginan pelanggan secara spesifik dari bentuk fisik produk atau jasa sampai pendistribusian yang tepat.

\section{Pelayanan prima dalam islam}

Pelayanan prima merupakan terjemahan "excellent service" yang berarti pelayanan terbaik atau sangat baik, dikatakan baik karena pelayanan yang diberikan sesuai dengan prosedur pelayanan yang berlaku atau dimiliki instansi pemberi pelayanan. Ketika pelayanan prima benar-benar diaplikasikan dalam kehidupan bermasyarakat atau dunia bisnis maka efek baik juga akan dirasakan diantaranya seperti loyalitas, kepercayaan, profit, perkembangan usaha akan meningkat hidup menjadi berkah silaturahmi terjaga, persatuan umat akan terjaga dan yang pasti surga akan didapat hal ini dijelaskan dalam Qs al-Baqarah ayat $267^{15}$ :

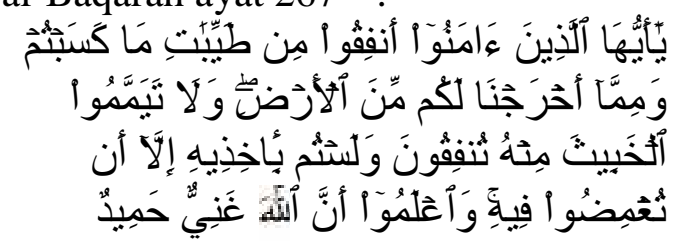

${ }^{15}$ Departemen Agama RI. op. cit. h. 56.
Artinya : "Hai orang-orang yang beriman, nafkahkanlah (di jalan Allah) sebagian dari hasil usahamu yang baikbaik dan sebagian dari apa yang kami keluarkan dari bumi untuk kamu. dan janganlah kamu memilih yang burukburuk lalu kamu menafkahkan daripadanya, padahal kamu sendiri tidak mau mengambilnya melainkan dengan memincingkan mata terhadapnya. dan Ketahuilah, bahwa Allah Maha Kaya lagi Maha Terpuji."

Dari ayat diatas jelas bahwa konsep islam mengajarkan dalam memberikan pelayanan dari usaha yang dijalankan baik itu berupa barang atau jasa jangan memberikan yang buruk atau tidak berkualitas melainkan yang berkualitas kepada orang lain maka islam sangat menganjurkan untuk memberikan layanan yang terbaik kepada orang lain.

1. Perbaikan SDM (Sumber Daya Manusia) Pelayanan

Bagi karyawan yang melayani konsumen dalam hal ini juga harus menyadari bahwa perusahan tengah berupaya untuk menjadi perusahaan dengan kualifikasi kelas dunia, oleh karenanya upaya peningkatan pelayanan tidak saja menjadi tanggung jawab SDM untuk mendukung kebijakan perusahaan tersebut. Beberapa sikap dan perilaku yang mendukung pelayanan yang baik adalah sebagai berikut:

a. Berupaya untuk menanamkan sikap jujur, bertanggung jawab, memiliki dedikasi dan komitmen dalam pelaksanaan tugas seharihari, tidak mengharapkan pujian maupun penghargaan dari orang lai, mau mendengarkan keluhan konsumen serta tetap bekerja sesuai dengan ekspektasi.

b. Memberikan pelayanan tanpa pandang buluh dengan dengan 
tidak membeda-bedakan siapa yang harus dilayani. Harus ikhlas menerima kekurangan diri, berusaha untuk bekerja dengan seluruh kemampuan, memberikan pelayanan kepada konsumen dengan sebaikbaiknya,serta membuka diri untuk terus menerus belajar dan meningkatkan kemampuan.

Membentuk kemampuan melayani tidak semudah apa yang dibayangkan, pembentukan kemampuan melayani harus segara dimulai sejak saat ini, walaupun mungkin bisa saja dikatan terlambat. Sebab untuk mendapatkan padi dengan kualitas bagus, tidak bisa ditanam tanpa persiapan yang cukup, lahan yang telah cukup diolah dan benih padi yang unggul. ${ }^{16}$

\section{Kepuasan}

Kepuasan menurut Freddy Rangkuti yang dikutip dalam buku Kotler kepuasan nasabah adalah perasaan senang atau kecewa seseorang sebagai hasil dari perbandingan anatara prestasi atau produk yang dirasakan dan di harapkan. ${ }^{17}$

Setiap orang melakukan pembelian dengan harapan tertentu mengenai apa yang di lakukan, dan kepuasan merupakan hasil yang di harapkan. Kepuasan atau ketidak puasan adalah perasaan senang atau kecewa seseorang yang berasal dari perbandingan antara kesannya terhadap kinerja produk yang riiil/ actual dengan kinerja produk yang di harapkan.

Menurut Zeithaml dan Bitner dalam Etta Mamang Sangadji dan

\footnotetext{
${ }^{16}$ Bahrul Kirom, Mengukur Kinerja Pelayanan dan Kepuasan konsumen, Bandung, Pustaka Reka Cipta, 2015, h. 204.

${ }^{17}$ Freddy Rangkuti, Meangsuring Customer Saticfactiont Teknik mengukur dan Strategi Meningkatkan Kepuasaan Pelanggan Plus Analisis Kasun PLN-JP, Jakarta, Gramedia Pustaka Utama, 2003, h. 13.
}

Sopiah (2013), kepuasan konsumen merupakan 'cutomer's evaluation of product of service in terms of whether that product or service has met their needs and expectation." Konsumen yang merasa puas pada produk / jasa yang di beli di gunakannya akan kembali menggunakan jasa / produk yang di tawarkan $^{18}$

Menurut Susatyo Herlambang (2014) Kepuasan adalah tingkat perasaan seseorang setelah membandingkan kinerja (atau hasil) yang dirasakan dibandingkan dengan harapan. Jadi tingkat kepuasan adalah fungsi dari perbedaan antara kinerja yang dirasakan dengan harapan seseorang. ${ }^{19}$

Dari beberapa pendapatan tentang pengertian kepuasan nasabah di atas dapat disimpulkan bahwa kepuasan nasabah merupakan tercapainya harapan konsumen terhadap keinginan dan kebutuhannya sehingga konsumen merasa puas.

4. Tahap pasca pembelian produk yang dilalui konsumen

Setelah mengonsumsi produk, konsumen akan merasakan kepuasan atau kekecewaan. Kepuasan akan mendorong konsumen untuk membeli ulang produk. Sebaliknya, jika kecewa, konsumen tidak akan membeli produk yang sama lagi di kemudian hari. Kepuasan konsumen merupakan evaluasi purna beli dimana alternative yang di pilih sekurang-kurangnya sama atau melampaui harapan konsumen. Kekecewaan timbul apa bila kinerja yang actual tidak memenuhi harapan konsumen. Ada lima tahap pasca pembelian produk yang di lalui konsumen, yaitu :

a. Konsumsi produk

b. Perasaan puas atau tidak puas

\footnotetext{
${ }^{18}$ Etta Mamang Sangadji dan Sopiah, Perilaku ......., h. 180-181.

${ }^{19}$ Susatyo Herlambang, Basic Marketing, Yogyakarta, Gosyen Publishing, 2014, h. 77.
} 
c. Perilaku keluhan konsumen

d. Disposisi barang

e. Pembentukan kesetiaan merek.

\section{Faktor-faktor Penunjang Kepuasan Pelanggan}

Pelanggan tidak membeli produk atau jasa, melainkan membeli sebuah manfaat. Saat pelanggan puas terhadap manfaat pelayanan yang telah mereka terima maka kan memberikan dampak yang baik. Seorang pelanggan yang puas dan memperoleh manfaat akan bercerita kepada orang-orang terdekat, secara tidak sadar mereka ikut memasarkan pelayanan yang telah mereka terima atau berpromosi kepada orang lain.

Untuk mencapai kepuasan pelanggan dalam konteks pelayanan diperlukan beberapa kondisi dan usaha, antara lain:

a. Pemahaman tentang filosofi kepuasan pelanggan

b. Mengenal kebutuhan atau harapan pelanggan

c. Membuat standard pengukuran kepuasan pelanggan

d. Orientasi karyawan dalam pelayanan

e. Pelatihan

f. Keterlibatan karyawan

g. Pengakuan dan penghargaan Sedangkan sebagai seorang petugas dalam lembaga pelayanan, ada empat unsure pokok yang harus dimiliki petugas, yaitu:
a. Keterampilan
b. Efisiensi, yaitu target "zero defect" dan tepat waktu "deadline"
c. Ramah, dan
d. Rasa bangga

Faktor-faktor penunjang dalam rangka memberikan pelayanan yang bermutu, terdiri dari:

a. Sikap
Sikap yang menunjang keberhasilan dalam pelayanan pelanggan yang bermutu, adalah Percaya diri, selalu berfikir dan bersikap positif, service oriented (berorientasi melayani bukan dilayani), disiplin, sopan, ramah dan terbuka, memiliki kemampuan untuk memberikan konsultasi, memiliki semangat dan energy, memilki kemampuan untuk toleransi terhadap keadaan-keadanan yang dapat menimbulkan frustasi, memiliki kemampuan untuk mengambil keputusan, dedikasi tinggi dan setia terhadap perusahaan, dapat bekerjasama, bersikap dewasa (tidak kekenakkanakan), dapat mengontrol diri sendiri, visioner (memiliki pandangan yang jauh kedepan mengenai kerjaan dan karir), mampu berkomunikasi dengan baik, Menampilkan citra diri yang tepat.

b. Mempunyai etika dan etiket

Dengan memperhatikan etiket pergaulan akan menunjang keberhasilan dalam pelayanan pelanggan yang bermutu, etiket tersebut adalah sebagai berikut:

1) Kesan pertama dan kesan terakhir yang baik

2) Memberikan kesan positif terhadap diri anda dan perusahaan

3) Sikap sopan dalam menerima tamu atau bertamu

4) Sikap tubuh yang baik

5) Etika berbicara, bertelepon, dan berbusana

c. Komunikasi

Komunikasi pada intinya adalah penyampaian pesan, yang dapat dilakukan secara langsung maupun tidak langsung. Yang harus diperhatikan dalam berkomunikasi:

1) Secara verbal:

Mudah dimengerti dan jelas, pernapasan baik, tidak menggunakan kata-kata yang sulit dimengerti atau kasar, tinggi nada 
suara tepat, hangat dan bersahabat, aksen daerah tidak kental, intonasi tepat, tidak monoton, ekspresif, pengucapan kata-kata tepat, tidak menggunakan bahasa slank

2) Secara non verbal

Kontak mata, ekspresi wajah, senyum, gerakan tubuh dan sikap tubuh.

3) Menjadi pendengar yang baik Mampu berempati dan bersimpati, bisa memberikan pendapat, dapat mengingant halhal terpernting, respon atau interupsi pada saat yang tepat, bermutu, dan mendukung, mendengarkan dan belajar.

4) Penampilan diri

Didalam dunia bisnis, penampilan lebih kepada sikap respek terhadap orang lain, terhadap pelanggan. Penampilan juga mencerminkan tingkat profesionalisme. Penampilan yang baik hendaknya selalu dalam keadaan rapi dan bersih, menghadirkan kepribadian yang sesuai dengan waktu, situasi, tujuan, serta tempat pertemuan. ${ }^{20}$

\section{Dimensi untuk meraih dan meningkatkan kepuasan nasbah ${ }^{21}$}

Terdapat beberapa teori dan metode untuk meraih simpati dan meningkatkan kepuasan nasabah, diantaranya adalah :

a. Pemasaran Relationship

Marketing

Transaksi antara pembelian dan penjualan berlanjut setelah penjualan selesai dengan kata lain, dijalin suatu komitmen dengan pelanggan secara terus menerus yang pada akhirnya akan menimbulkan kesetiaan

${ }^{20}$ Ibid. h. 79-82

${ }^{21}$ Freddy Rangkuti, h. $40-45$ pelanggan sehingga terjadi bisnis ulang.

b. Customer Superior Service

Meberikan menawarkan pelayanan yang lebih baik dari pada pesaing dana yang besar, sumber daya manusia yang handal, dan usaha yang gigih diperlukan agar perusahaan dapat menciptakan pelayanan yang superior.

c. Unconditional Guarantees

Memberikan garansi atau jaminan istimewa secara mutlak yang dirancang untuk meningkatkan resiko atau kerugian dipihak pelanggan, garansi tersebut menjanjikan kualitas prima dan kepuasan pelanggan yang optimal.

d. Penanganan keluhan yang Efisien Proses penanganan keluhan pelanggan yang efektif dimulai dari identifikasi dan penentuan sumber masalah yang menyebabkan pelanggan tidak merasa puas dan mengeluh.

e. Peningkatkan Kinerja Perusahaan

Perusahaan menetapkan cara yang dapat meningkatkan kualitas pelayanan secara berkesinambungan, memberikan pendidikan dan pelatihan komunikasi, salesmanship, dan public relations kepada pihak menajemen dan karyawan, memasukan pelanggan ke dalam system penilaian prestasi karyawan.

\section{Loyalitas Nasabah}

Loyalitas secara harfiah diartikan kesetiaan, yaitu kesetiaan seseorang terhadap suatu objek. Menurut istilah loyalitas pelanggan sebetulnya berasal dari loyalitas merek yang mencerminkan loyalitas pelanggan pada merek tertentu. Loyalitas pelanggan dan loyalitas merek menunjukkan hal yang sama, oleh karena itu penggunaannya tidak 
dibedakan dan dapat diutarakan secara silih berganti.

Menurut Oliver dalam Hurriyati dalam kutipan buku Sangadji dan Sopiah (2013) menyatakan bahwa loyalitas adalah "komitmen pelanggan bertahan secara mendalam untuk berlangganan kembali atau melakukan pembelian ulang produk atau jasa terpilih secara konsisten dimasa yang akan datang, meskipun peangaruh situasi dan usahausaha pemasaran mempunyai potensi untuk menyebabkan perubahan perilaku. $" 22$

Jadi loyalitas pelanggan merupakan pembelian secara teratur dan berulang-ulang datang atau untuk membeli ke suatu tempat yang sama untuk memuaskan keinginannya dengan membeli suatu produk atau jasa.

1. Jenis Loyalitas

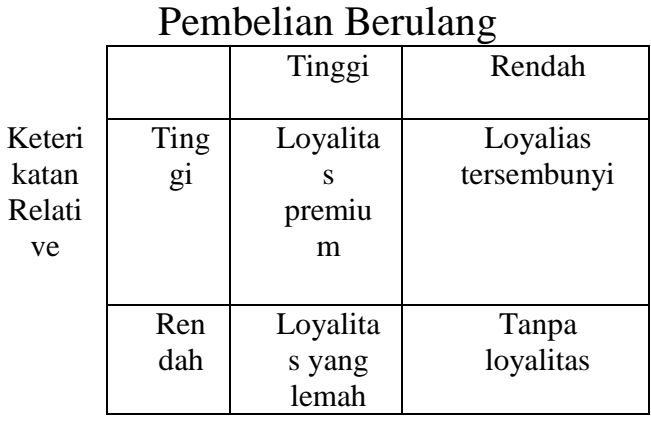

Gambar 2.1. Empat Jenis Loyalitas

Setelah keterikatan, factor kedua yang menentukan loyalitas pelanggan terhadap produk atau jasa tertentu adalah pembelian berulang. Empat jenis loyalitas yang berbeda muncul bila keterikatan rendah dan tinggi diklasifikasi silang dengan pola pembelian ulang yang remdah dan tinngi.

a. Tanpa Loyalitas Untuk berbagai alasan, beberapa pelanggan tidak mengembangkan loyalitas

${ }^{22}$ Etta Mamang Sangadji dan Sopiah. h. 104. terhadap produk atau jasa tertentu.

b. Loyalitas yang lemah

Keterikatan yang rendah digabungkan dengan pembelian berulang yang tinggi menghasilkan loyalitas yang lemah. Pelanggan membeli karena kebiasaan.

c. Loyalitas Tersembunyi

Tingat preferensi yang relative tinggi digabung dengan tingkat pembelian berulang yang rendah menunjukkan loyalitas tersembunyi. Bila pelanggan memiliki loyalitas yang tersembunyi, pengaruh situasi dan bukan pengaruh sikap yang menentukan pembelian berulang.

d. Loyalitas Premium

Loyalitas premium, jenis loyal yang paling dapat ditingkatkan, terjadi bila ada tingkat keterkaitan yang tinggi dan tingkat pembelian berulang yang juga tinggi. Ini merupakan jenis loyalitas yang lebih disukai untuk semua pelanggan di setiap perusahaan. Pada tingkat preferensi paling tinggi tersebut, orang bangga karena menemukan dan menggunakan produk tertentu dan senang membagi pengetahuan mereka dengan rekan dan keluarga. ${ }^{23}$

2. Tahapan - tahapan Loyalitas

Proses seorang pelanggan menjadi pelanggan yang loyal terhadap perusahaan terbentuk melalui beberapa tahapan. Griffin dalam Etta Mamang Sangadji dan Sopiah (2013)

\footnotetext{
${ }^{23}$ Griffin, jill. Customer Loyalty. Jakarta.

Erlangga. 2005. h. 22-23

${ }^{24}$ Etta Mamang Sangadji dan Sopiah......... h. 106108.
} 
mengemukakan loyalitas pelanggan dibagi menjadi 6 tahapan, yaitu:

a. Terduga (suspects)

Meliputi semua orang yang mungkin akan membeli barang atau jasa perusahaan, tetapi sama sekali belum mengenal perusahaan dan barang atau jasa yang ditawarkan.

b. Prospek (prospects)

Merupakan orang-orang yang memliki kebutuhan akan produk atau jasa tertentu dan mempunyai kemampuan untuk membelinya. Meskipun belum melakukan pembelian, para prospek telah mengetahui keberadaan perusahaan dan barang atau jasa yang ditawarkan karena seseorang telah merekomendasikan barang atau jasa tersebut kepadanya.

c. Prospek terdiskualifikasi (disqualified prospects)

Yaitu prospek yang telah mengetahui kebaradaan barang atau jasa tertentu, tetapi tidak mempunyai kebutuhan akan barang atau jasa tersebut, atau tidak mempunyai kemapuan membeli barang atau jasa tersebut,

d. Pelanggan mula-mula (first time customer)

Yaitu pelanggan yang membeli untuk pertama kalinya, mereka masih menjadi pelanggan yang baru.

e. Pelanggan berulang (repeat custoemer)

Yaitu pelanggan yang telah membeli produk yang sama sebanyak dua kali atau lebih, atau membeli dua macam produk yang berbeda dalam dua kesempatan yang berbeda pula.

f. Klien
Klien membeli semua barang atau jasa yang ditawarkan dan dibutuhkan, mereka membeli secara teratur. Hubungan dengan jenis pelanggan ini sudah kuat dan berlangsung lama, yang membuat mereka tidak terpengaruh oleh produk pesaing.

g. Pendukung (advocates)

Seperti halnya klien, pendukung membeli barang atau jasa yang ditawarkan dan dibutuhkan, serta melakukan pembelian secara teratur. Selain itu, mereka mendorong temanteman mereka agar membeli barang atau jasa perusahaan atau merekomendasikan perusahaan tersebut pada orang lain. Dengan begitu, secara tidak langsung mereka telah melakukan pemasaran dan membawa pelanggan untuk perusahaan.

h. Mitra, merupakan bentuk hubungan yang paling kuat antara pelanggan dan perusahaan, dan berlangsung terus-menerus karena kedua pihak melihatnya sebagai hubungan yang saling menguntungkan.

3. Karakteristik Loyalitas

Loyalitas pelanggan merupakan ukuran yang dapat diandalkan untuk memprediksi pertumbuhan penjualan dan juga loyalitas pelanggan dapat didefinisikan berdasarkan perilaku pembelian yang konsisten (Griffin, $2005)^{25}$. Berikut adalah karakteristik dari loyalitas konsumen:

a. Melakukan pembelian berulang secara teratur

Konsumen melakukan pembelian secara continue pada

\footnotetext{
${ }^{25}$ Jill Griffin, Costumer.......... h. 33-34.
} 
suatu produk tertentu. Contoh: pencinta motor Harley Davidson akan membeli motor Harley baru jika ada model Harley Davidson yang terbaru, bahkan tidak hanya membeli tetapi mereka juga mengeluarkan uang tambahan untuk mengubahnya sesuai dengan keinginan mereka.

b. Membeli antar lini produk atau jasa (purchase across product and service lines)

Konsumen tidak hanya membeli jasa dan produk utama tetapi konsumen juga membeli lini produk dan jasa dari perusahaan yang sama. Contoh: konsumen tidak hanya membeli motor Harley Davidson saja, tetapi mereka juga membeli aksesoris dari Harley Davidson untuk mempercantik motor mereka.

c. Mereferensikan kepada orang lain (Refers other)

Dimana konsumen

melakukan komunikasi dari mulut ke mulut (word of mouth) berkenaan dengan produk tersebut. Contoh: seorang konsumen Harley Davidson yang sudah lama memakai motor tersebut, menceritakan tentang kehebatan dan keunggulan dari motor tersebut, kemudian setelah itu temannya tertarik untuk membeli motor Harley Davidson karena mendengar cerita tersebut.

d. Menunjukkan kekebalan terhadap tarikan dari pesaing (demonstrates an immunity to the full of the competition)

Konsumen menolak untuk menggunakan produk atau jasa alternatif yang ditawarkan oleh pesaing. Contoh: para pencinta motor Harley Davidson menolak untuk menggunakan motor lain, bahkan mereka juga cenderung menolak untuk mengetahui ada jenis-jenis motor lainnya.

Pelanggan yang loyal merupakan aset bagi perusahaan, hal ini dapat dilihat berdasarkan karakteristik yang dimiliknya. Oleh karena itu, loyalitas konsumen merupakan suatu ukuran yang bisa diandalkan untuk memprediksi pertumbuhan dimasa yang akan datang bagi suatu perusahaan.

4. Memperhatikan Loyalitas Pelanggan Menurut Zeithaml dan Bitner dalam Etta Mamang Sangadji dan Sopiah $(2013)^{26}$ mengemukakan untuk mewujudkan dan mempertahankan loyalitas pelanggan dibutuhkan langkah kunci yang saling terikat, yaitu:

a. Komitmen dan keterlibatkan manajemen puncak

Dalam setiap keputusan strategis organisasi, peranan penting manajemen puncak perlu dimainkan. Dukungan, komitmen, kepemimpinan, dan partisipasi aktif manajemen puncak selalu dibutuhkan untuk melakukan transformasi budaya organisasi, struktur kerja, dan prak, dan partisipasi aktif manajemen puncak selalu dibutuhkan untuk melakukan transformasi budaya organisasi, struktur kerja, dan praktek manajemen SDM dari paradigma tradisional menuju paradigma pelanggan.

b. Tolak ukur internal (internal benchmarketing)

Proses tolak ukur internal meliputi pengukuran dan penilaian atas manajemen, SDM, organisasi, system, alat, desain, pemasok, pemanufakturan, pemasaran dan jasa pendukung perusahaan. Adapun ukuran-ukuran yang digunakan meliputi loyalitas pelanggan (jumlah persentase dan kelanggengannya),

${ }^{26}$ Etta Mamang Sangadji dan Sopiah, h. 110-111. 
nilai tambah bagi pelanggan inti, dan biaya akibat kualitas yang jelek.

c. Identifikasi kebutuhan pelanggan Identifikasi kebutuhan pelanggan dapat dilakukan dengan beberapa metode mutakhir seperti riset nilai (value research), jendela pelanggan (customer window), model, analisis sentivitas, evaluasi multiatribut, analisiis conjoin, dan quality function deployment (QFD).

d. Penelitian kapabilitas persaingan

Dalam era hiperkompetitif ini pemahaman mengenai aspek internal perusahaan dan pelanggan saja tidak memadahi. Untuk memenangkan persaingan, kapabilitas pesaing (terutama yang terkuat) harus didentifikasikan dan dinilai secara cermat.

e. Pengukuran kepuasan dan loyalitas pelanggan

Keputusan pelanggan menyangkut apa yang diungkapkan oleh pelanggan, sedangkan loyalitas pelanggan berkaitan dengan apa yang dilakukan pelanggan.

f. Analisis umpan balik dari pelanggan, mantan pelanggan, non pelanggan, dan pesaing

Lingkup analisis perusahan perlu diperluas dengan melibatkan mantan pelanggan dan non pelanggan, tentu selain pelanggan saat ini dan pesaing. Dengan demikian, perusahaan bisa memahami dengan lebih baik faktor-faktor yang menunjang kepuasan dan loyalitas pelanggan, serta faktor negatif yang berpotensi menimbulkan pembelotan pelanggan (customer defection).

g. Perbaikan berkesinambungan

Loyalitas pelanggan merupakan berjalanan tanpa akhir. Tidak ada jaminan bila sudah terwujud, lantas loyalitas bisa langgeng dengan sendirinya. Pada prinsipnya, perusahaan harus aktif mencari berbagi inovasi dan terobosan untuk merespons setiap perubahan yang menyangkut faktor 3C (customer, company, dam competitors).

\section{Profil (KSPPS) BMT Al-Falah Berkah Sejahtera}

Kemiskinan memang masih menjadi sebuah tantangan besar bagi bangsa ini untuk segera ditangani, mengingat dampak sosial yang ditimbulkan dari akibat maraknya kemiskinan sangat berakibat buruk terhadap nilai tatanan sosial masyarakat itu sendiri. Korupsi, kekerasan, bahkan sampai menghilangkan nyawa demi mencukupi kebutuhan hidup sehari-hari menjadi berita yang sering kali kita dengar saat ini.BMT AL-FALAH sebagai sebagai sebuah lembaga keuangan mikro koperasi dengan badan hukum Nomor 09/BH/KDK10.17/IX/1998 sudah tumbuh sejak 1995 terus berupaya memberdayakan masyarakat kecil (mikro) bawah untuk tetap eksis mengembangkan usahanya untuk memenuhi hajat hidupnya, khususnya masyarakat di wilayah Cirebon kota dan kabupaten. Bentuk kepedulian kami adalah memberikan bantuan permodalan kepada para pelaku usaha kecil bawah (pedagang) serta memberikan edukasi kewirausahaan berdasarkan syari'ah yang berhubungan langsung dengan sektor usaha riil yang dijalani masyarakat saat ini.

Usaha kecil merupakan kegiatan ekonomi yang mendominasi lebih dari $75 \%$ struktur perekonomian Indonesia.Sektor ini memiliki peran strategis baik secara ekonomi maupun sosial politik. Fungsi ekonomi sektor ini antara lain menyediakan barang \& jasa bagi konsumen berdaya beli rendah sampai sedang. Menyumbang lebih dari separuh pertumbuhan ekonomi serta 
memberikan kontribusi dalam perolehan devisa negara. Secara sosial politik fungsi sektor ini juga sangat penting terutama dalam penyerapan tenaga kerja serta upaya pengentasan kemiskinan.

Ekonomi Syariah yang merupakan bagian penting dari sistem perekonomian kita, memiliki karakteristik dan nilai-nilai yang berkonsep kepada amar ma'ruf nahi mungkar yang berarti mengerjakan yang benar dan meninggalkan yang dilarang. Ekonomi Syariah dapat dilihat dari 4 (empat) sudut pandang, yaitu: Pertama, Ekonomi Illahiyah (Ke-Tuhan-an); Kedua, Ekonomi Akhlaq; Ketiga, Ekonomi Kemanusiaan; dan Keempat, Ekonomi Keseimbangan.

Sementara Ekonomi syariah dalam waktu singkat tumbuh dan berkembang mengisi khazanah keislaman bumi Indonesia, Lembaga keuangan syariah yang merupakan bagian dari ekonomi Islam pun turut berkembang dalam rangka mendukung dunia usaha.Salah satu lembaga keuangan syariah yang terus berkembang sesuai dengan perkembangan ekonomi dan penduduk adalah Baitul Maal Wattamwil (BMT).

BMT merupakan suatu lembaga ekonomi mikro, yang berupaya mengembangkan usaha-usaha produktif dan investasi dalam meningkatkan kegiatan ekonomi pengusaha kecil dan kecil bawah berdasarkan prinsip syariah dan prinsip koperasi.Profil ini adalah sumbangsih BMT bagi para pelaku ekonomi serta masyarakat untuk mengenalkan dan menjadikan lembaga keuangan syariah sebagai pilihan untuk berhijrah menuju ekonomi yang islami.

2. Sejarah Singkat

BMT Al-Falah merupakan Lembaga Jasa Keuangan Mikro Syariah yang berbadan hukum koperasi, didirikan dan dilatarbelakangi dengan adanya program Ikatan Cendikiawan
Muslim Indonesia (ICMI) Orsat Kabupaten Cirebon dalam rangka pengentasan kemiskinan melalui pendirian BMT di Kecamatan seWilayah Kabupaten Cirebon, dan dicanangkannya BMT sebagai Gerakan Nasional oleh Presiden RI pada Desember $1995 . \quad$ Sebagai implementasinya, didirikanlah BMT ALFALAH di Kelurahan Sumber, Kecamatan Sumber Kabupaten Cirebon. Diresmikan oleh Bapak Ir. H. Tb. Hisni pada tanggal 10 November 1995 dan mulai beroperasi pada tanggal 14 Desember 1995 dengan legalitas sebagai Kelompok Swadaya Masyarakat yang berada di bawah pengawasan PINBUK berdasarkan naskah kerjasama YINBUK dengan PHBK Bank Indonesia*.Selanjutnya dalam rangka memperoleh Badan Hukum, maka pada tahun 1998 secara resmi BMT AlFalah menggunakan legalitas Badan Hukum Koperasi dengan Nomor 09/BH/KDK10.17/IX/1998 pada tanggal 23 September 1998.

Selanjutnya

perubahan

ANGGARAN DASAR KJKS BMT ALFALAH telah secara resmi disahkan oleh Bupati Cirebon Ub. Kepala Dinas Koperasi, UMKM atas nama Menteri Negara Koperasi, Usaha Mikro, Kecil dan Menengah Republik Indonesia, berdasarkan SK No. 05/PAD/KUMKM/XI/2010 tertanggal 29 Nopember 2010.

Saat ini BMT AL FALAH berkantor pusat di Jl. Sultan Agung No. 09 Sumber Kabupaten Cirebon 45611 Telpon 0231-8330138, memiliki kantor cabang yang tersebar di kota dan kabupaten Cirebon, Majalengka, Indramayu dan Kuningan. Berikut daftar kantor BMT Al-Falah di wilayah III Cirebon.

\section{Pengujiana Hipotesis}

1. Analisis Regresi Berganda 
Regresi berganda merupakan teknik statistika yang dapat digunakan untuk menganalisa hubungan antara variabel dependen dan variabel independen. Tujuan dari analisis regresi berganda adalah untuk mengetahui signifikansi pengaruh variabel independen terhadap variabel dependen, sehingga dapat memuat prediksi yang tepat.

Berdasarkan data penelitian yang dikumpulkan baik untuk variabel terikat (Y) maupun variabel bebas (X1 dan X2) yang diolah dengan menggunakan bantuan program SPSS 16, maka diperoleh hasil perhitungan regresi linear berganda sebagai berikut:

Coefficients $^{a}$

\begin{tabular}{|c|c|c|c|c|c|c|}
\hline \multirow{2}{*}{\multicolumn{2}{|c|}{ Model }} & \multicolumn{2}{|c|}{ Unstandardized Coefficients } & \multirow{2}{*}{$\begin{array}{c}\text { Standardized } \\
\text { Coefficients } \\
\text { Beta }\end{array}$} & \multirow[b]{2}{*}{$\mathrm{t}$} & \multirow[b]{2}{*}{ Sig. } \\
\hline & & $\mathrm{B}$ & Std. Error & & & \\
\hline \multirow[t]{3}{*}{1} & (Constant) & 6.250 & 1.933 & & 3.233 & .002 \\
\hline & pelayanan $(\mathrm{X} 1)$ & .081 & .035 & .265 & 2.351 & .021 \\
\hline & kepuasan (X2) & .240 & .091 & .298 & 2.644 & .010 \\
\hline
\end{tabular}

a. Dependent Variable: loyalitas (Y)

\subsection{9}

Dari data diatas dapat diperoleh persamaan regresi linear berganda sebagai berikut:

$\mathrm{Y}=6,250+0,081+0,240$

Dimana: 6,250 : Variabel independen yaitu pelayanan dan kepuasan anggota mempunyai hubungan positif dengan loyalitas anggota pembiayaan. Nilai konstanta loyalitas anggota sebesar 6,250 menunjukakan bahwa semakin meningkatnya pelayanan jasa yang diberikan akan berpengaruh terhadap kepuasan dan keloyalitasan yang dirasakan oleh anggota. 0,081 : Variabel pelayanan berpengaruh positif terhadap loyalitas anggota. 0,240 :

Variabel kepuasan berpengaruh positif terhadap loyalitas anggota.

Dari uraian model regresi berganda di atas menunjukkan bahwa variabel pelayanan dan kepuasan memiliki nilai positif yang artinya terjadi tingkat loyalitas anggota.

\section{Uji Parsial T}

Uji terhadap nilai statistik $t$ merupakan uji signifikansi parameter c. individual. Nilai statistik t menunjukkan seberapa jauh pengaruh variabel independen secara individual terhadap variabel dependennya. Uji t dilakukan dengan antara $t_{\text {hitumg }}$ dan $t_{\text {tabel }}$ pada tingkat signifikansi 5\%. Jika nilai $t_{\text {hitumg }}$ lebih besar dibandingkan dengan $t_{\text {tabel }}$ maka dapat disimpulkan bahwa variabel tersebut memiliki pengaruh yang signifikan atau sebaliknya.

Keputusan dalan uji $\mathrm{t}$ :

a. Jika $t_{\text {hitung }}>t_{\text {tabel }}$ maka ada pengaruh pelayanan (X1) dan kepuasan (X2) terhadap loyalitas anggota $(\mathrm{Y})$ atau $\mathrm{Ha}=$ terdapat pengaruh pelayanan (X1) dan kepuasan (X2) terhadap loyalitas anggota (Y).

b. Jika $t_{\text {hitung }} \mathrm{t}_{\text {tabel }}$ maka tidak ada pengaruh pelayanan (X1) dan kepuasan (X2) terhadap loyalitas anggota $(\mathrm{Y})$ atau $\mathrm{Ho}=$ tidak terdapat pengaruh pelayanan $(\mathrm{X} 1)$ dan kepuasan (X2) terhadap loyalitas anggota (Y). 
Coefficients $^{a}$

\begin{tabular}{|c|c|c|c|c|c|c|}
\hline \multirow{2}{*}{\multicolumn{2}{|c|}{ Model }} & \multicolumn{2}{|c|}{ Unstandardized Coefficients } & \multirow{2}{*}{$\begin{array}{c}\begin{array}{c}\text { Standardized } \\
\text { Coefficients }\end{array} \\
\text { Beta }\end{array}$} & \multirow[b]{2}{*}{$\mathrm{t}$} & \multirow[b]{2}{*}{ Sig. } \\
\hline & & $B$ & Std. Error & & & \\
\hline \multirow[t]{3}{*}{1} & (Constant) & 6.250 & 1.933 & & 3.233 & .002 \\
\hline & pelayanan $(\mathrm{X} 1)$ & .081 & .035 & .265 & 2.351 & .021 \\
\hline & kepuasan (X2) & .240 & .091 & .298 & 2.644 & .010 \\
\hline
\end{tabular}

a. Dependent Variable: loyalitas $(Y)$

Dari hasil uji parsial (t) terlihat bahwa :

Variabel pelayanan memiliki nilai probabilitas (sig) sebesar $0,021>$ 0,05 . Dengan demikian Ho ditolak dan Ha diterima atau pengaruh pelayanan terhadap loyalitas anggota pembiayaan pada BMT Al-Falah Sumber Cirebon adalah tidak signifikan.

Variabel kepuasan memiliki nilai probabilitas (sig) sebesar 0,010>0,05. Dengan demikian Ho ditolak dan $\mathrm{Ha}$ diterima atau pengaruh kepuasan terhadap loyalitas anggota pembiayaan pada BMT Al-Falah Sumber Cirebon adalah tidak signifikan.

Dapat disumpulkan bahwa uji $\mathrm{t}$ dari pelayanan dan kepuasan diperoleh nilai sig $>0,05$ atau $t_{\text {hitung }}>t_{\text {tabel. }}$ Sehingga hipotesis yang menyatakan bahwa berpengaruh signifikan terhadap loyalitas anggota secara parsial ditolak.

3. Nilai statistik F

Nilai statistik $\mathrm{F}$ menunjukkan apakah semua variabel independen yang dimasukkan dalam persamaan/model regresi secara bersamaan berpengaruh terhadap variabel dependen.

Ketentuan penerimaan hipotesis yaitu :

Ho ditolak bila sig $>0,05$ atau $\mathrm{f}_{\text {hitung }}<\mathrm{f}_{\text {tabel }}$

Ha diterima bila sig $<0,05$ atau $f_{\text {hitung }}>f_{\text {tabel }}$

Nilai Statistik F

ANOVA $^{\mathrm{D}}$

\begin{tabular}{|c|c|c|c|c|c|c|}
\hline \multicolumn{2}{|c|}{ Model } & Sum of Squares & Df & Mean Square & $\mathrm{F}$ & Sig. \\
\hline \multirow[t]{3}{*}{1} & Regression & 66.819 & 2 & 33.409 & 14.565 & $.000^{\circ}$ \\
\hline & Residual & 201.862 & 88 & 2.294 & & \\
\hline & Total & 268.681 & 90 & & & \\
\hline
\end{tabular}

a. Predictors: (Constant), kepuasan (X2), pelayanan (X1)

b. Dependent Variable: loyalitas $(\mathrm{Y})$

Dari tabel diatas diperoleh nilai

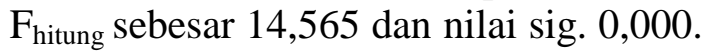
Kemudian mencari $F_{\text {tabel }}$ dan membandingkan dengan $F_{\text {hitung }}$ dengan menggunakan batas signifikan 0,05 dan $F_{\text {tabel }}$ 2,32. Dapat dilihat bahwa $F_{\text {hitung }}>$ $F_{\text {tabel }}$ yaitu $14,565>2,32$ yang artinya Ho ditolak dan Ha diterima. Dengan demikian maka hipotesis uji $\mathrm{F}$ pelayanan secara bersama-bersama berpengaruh secara positif dan dapat diterima atau terdapat pengaruh pelayanan dan kepuasan terhadap loyalitas anggota pembiayaan pada BMT Al-Falah Sumber Cirebon.

\section{Koefisien Determinasi $\left(\mathbf{R}^{2}\right)$}

Koefisien determinasi sebenarnya mengukur besarnya presentase pengaruh semua variabel independen dalam model regresi terhadap variabel dependennya. Besarnya nilai koefisien determinasi berupa presentase yang menunjukkan 
presentase variasi nilai variabel yang dapat dijelaskan oleh model regresi. Apabila nilai koefisien determinasi dalam model regresi semakin kecil (mendaki nol) berarti semakin kecil semua variabel independen terhadap variabel dependennya. Atau dengan kata lain, nilai $\mathrm{R}^{2}$ yang kecil berarti kemampuan semua variabel independen dalam menjelaskan variabel dependen sangat terbatas. Sebaliknya, apabila $\mathrm{R}^{2}$ semakin mendekati $100 \%$ berarti semua variabel independen dalam model memberikan hampir semua informasi yang diperlukan untuk memprediksi variabel dependennya atau semakin besar pengaruh semua variabel independen terhadap veriabel dependen. Nilai $R$ yang diperoleh akan dijelaskan pada tabel sebagai berikut ini :

Nilai Kofesien Determinasi $\left(\mathrm{R}^{2}\right)$

\begin{tabular}{|c|c|c|c|c|c|}
\hline \multicolumn{6}{|c|}{ Model Summary ${ }^{b}$} \\
\hline $\begin{array}{l}\text { Mode } \\
\text { I }\end{array}$ & $\mathrm{R}$ & $\begin{array}{c}\mathrm{R} \\
\text { Squa } \\
\text { re }\end{array}$ & $\begin{array}{l}\text { Adjust } \\
\text { ed R } \\
\text { Square }\end{array}$ & $\begin{array}{c}\text { Std. } \\
\text { Error } \\
\text { of the } \\
\text { Estim } \\
\text { ate }\end{array}$ & $\begin{array}{l}\text { Durbin- } \\
\text { Watson }\end{array}$ \\
\hline 1 & .499 & .249 & .232 & 1.515 & 1.785 \\
\hline \multicolumn{6}{|c|}{$\begin{array}{l}\text { a. Predictors: (Constant), kepuasan } \\
\text { (X2), pelayanan (X1) }\end{array}$} \\
\hline \multicolumn{6}{|c|}{$\begin{array}{l}\text { b. Dependent Variable: loyalitas } \\
\text { (Y) }\end{array}$} \\
\hline
\end{tabular}

4.22

Dari tabel diatas menunjukkan Hasil Regresi linier Berganda Model summary nilai koefisien determinasi $\mathrm{R}$ yang menjukkan tingkat hubungan antara variabel bebas terhadap variabel terikat yaitu 0,499 artinya terdapat hubungan yang kuat. Dan R square atau Determinasi $\mathrm{R}^{2}$ menjukkan besarnya kontribusi sebesar 0,249 atau 24,9\% dari pelayanan dan kepuasan terhadap loyalitas anggota. Nilai ini mengandung arti bahwa pelayanan (X1) dan kepuasan (X2) terhadap loyalitas anggota (Y) sebesar $24,9 \%$ atau berarti loyalitas anggota dipengaruhi oleh variabel bebas, sedangkan sisanya $75,1 \%$ loyalitas anggota dipengaruhi oleh factor-faktor variabel lain yang tidak diteliti.

\section{Pembahasan Hasil Penelitian}

Hasil penemuan dari penelitian ini menunjukkan bahwa sistem pelayanan dan kepuasan anggota pembiayaan di BMT Al-Falah Sumber Cirebon dilaksanakan dengan baik dan berpegaruh signifikan terhadap peningkatan loyalitas anggota. Dimana kepuasan memiliki pengaruh terbesar dengan nilai $t_{\text {hitung }}=0,240$ dan kemudian pelayanan memiliki pengaruh sebesar $\mathrm{t}_{\text {hitung }}=0.081$. Untuk uji $\mathrm{t}$ dari pelayanan $(0,021)$ atau nilai sig. > dari 0,05 atau $t_{\text {hitung }}>t_{\text {tabel }}$. Sehingga hipotesis yang menyatakan bahwa berpengaruh signifikan terhadap loyalitas anggota pembiayaan secara parsial ditolak, kemudian untuk uji $\mathrm{t}$ dari kepuasan $(0,010)$ atau nilai sig. > dari 0,05 atau $t_{\text {hitung }}>t_{\text {tabel }}$. Sehingga hipotesis yang menyatakan bahwa berpengaruh signifikan terhadap loyalitas anggota pembiayaan secara parsial ditolak.

Dari hasil penelitian diketahui bahwa pengaruh system pelayanan dan kepuasan berpengaruh secara simultan terhadap loyalitas anggota sebesar 14,565, hali ini lebih diperjelas bahwa variabel pelayanan dan kepuasan tersebut memilki tingkat hubungan sebesar 0,499 terhadap loyalitas anggota. Dari tingkat hubungan tersebut didapat bahwa sistem pelayanan dan kepuasan memiliki kontribusi terhadap loyalitas anggota sebesar 0,249 atau 24,9\%, sementara sisanya 0.751 atau $75,1 \%$ loyalitas anggota dipengaruhi oleh factor-faktor variabel lain yang tidak diiteliti. Karena factor-faktor lain juga sangat ikut berpengaruh terhadap loylalitas anggota, sehingga dapat disimpulkan bahwa pengaruh system pelayanan dan kepuasan secara 
keseluruhan terhadap loyalitas anggota sebesar 24,9\% dapat diterima pada BMT Al-Falah Sumber Cirebon.

\section{KESIMPULAN}

Berdasarkan hasil analisis data dalam penelitian ini menunnjukkan bahwa variabel sistem pelayanan berpengaruh positif sebesar 0,081 tetapi dari hasil uji t nilai probabilitas (sig) tidak mempunyai pengaruh secara signifikan terhadap loyalitas anggota sebesar 0,021. Probabilitas (sig) sistem pelayanan sebesar 0,021 >0,05 dengan demikian Ho ditolak. Hal ini diinterpretasikan bahwa sistem pelayanan tidak mempunyai pengaruh yang signifikan terhadap loyalitas anggota pembiayaan di BMT Al-falah Sumber Cirebon. Sedangkan variabel kepuasan berpengaruh positif sebesar 0,240 tetapi dari hasil uji $t$ nilai probabilitas (sig) tidak mempunyai pengaruh secara signifikan terhadap loyalitas anggota sebesar 0,010>0,05 dengan demikian Ho ditolak. Hal ini diinterpretasikan bahwa kepuasan tidak mempunyai pengaruh yang signifikan terhadap loyalitas anggota pembiayaan di BMT Al-falah Sumber Cirebon. Dan hasil uji Pengaruh sistem pelayanan dan kepuasan terhadap loyalitas anggota pembiayaan di BMT Al-falah Sumber Cirebon sebesar 14,565. Bahwa diperoleh nilai $F_{\text {hitung }}$ sebesar 14,565 dan nilai sig. 0,000. Kemudian perbandingan antara $F_{\text {tabel }}$ dengan $F_{\text {hitung }}$ dengan menggunakan batas signifikan 0,05 dan $F_{\text {tabel }} 2,32$. Dapat dilihat bahwa $F_{\text {hitung }}>$ $F_{\text {tabel }}$ yaitu 14,565 $>2,32$ dengan demikian Ha diterima.

\section{Daftar Pustaka}

Departemen Agama RI, 2002, Al-Qur'an dan Terjemah juz 1-juz 30, Jakarta: Dana Karya.

Griffin, Jill. 2005 Customer Loyalty. Jakarta. Erlangga

Hasan, Ahmad Ridwan, 2013, Manajemen Baitul Mal wa Tamwil, Bandung, CV Pustaka Setia.

Hasan, Ali, 2010, Marketing Bank Syariah, Bogor, Ghalia Indonesia

Herlambang, Susatyo, 2014, Basic Marketing, Yogyakarta, Gosyen Publishing.

Kasmir, 2005, Etika Customer Service, Jakarta, Rajawali Press

Kirom, Bahrul, 2010, Mengukur Kinerja Pelayanan dan Kepuasan Konsumen, Bandung, Pustaka Reka Cipta.

Kuncoro, Mudrajat, 2007, Metode Riset Untuk Bisnis dan Ekonomi, Surabaya:Erlangga

Kotler, Phillip dan Keller 2009. Manajemen Pemasaran, Jakarta: Rajawali Press Grasindo

Lupiyoadi, Rambat, 2006, Manajemen Pemasaran Jasa : Teori dan Pratek, Jakarta: PT salemba Empat

Muhammad, : 2013, Managemen Bank Syariah, Yogyakarta: UPP AMP YKPN

Prasetyo, Bambang dan Lina Miftahul Jannah, 2013,Metode Penelitian 
Kuantitatif, Jakarta: PT Raja

Grafindo Persada

Rangkuti, Freddy, 2003, Meangsuring

Customer Saticfactiont Teknik

mengukur dan Strategi

Meningkatkan Kepuasaan

Pelanggan Plus Analisis Kasun

PLN-JP, Jakarta, Gramedia

Pustaka Utama,

Sangadji, Etta Mamang dan sopiah, 2012,

Metodologi Penelitian

Pendekatan Praktis dalam

Penelitian, Yogyakarta : Rineka

Cipta 